\title{
COMPLEX FORMATION OF DIOXOVANADIUM(V) WITH GLYCINE AND SOME GLYCYL PEPTIDES
}

\author{
Farrokh Gharib* and Rasoul Nasiri, \\ Chemistry Department, Shahid Beheshti University, \\ Tehran, Evin, Iran
}

\begin{abstract}
Stability constants for complexes between dioxovanadium(V) and glycine, glycylglycine, glycylalanine, and glycylphenylalanine have been determined by a combination of potentiometric and spectrophotometric techniques in aqueous solution at $25^{\circ} \mathrm{C}$ and $0.1 \mathrm{~mol} \mathrm{dm}^{-1}$ ionic strength $\left(\mathrm{NaClO}_{4}\right)$. Complex distribution curve depending on $\mathrm{pH}$ and metal-ligand ratio is given and influences of the side chains on the stability constants and the stoichiometries of the formed complexes are given and discussed.
\end{abstract}

\section{INTRODUCTION}

Over the past decade an extraordinary expansion of interest has evolved in the aqueous chemistry and biochemistry of vanadium cations, particularly of the $V(I V)$ and $V(V)$ oxidation states. Much of this interest has concentrated on complexation of these ions with a number of proteins, particularly albumines, transferins and as activator in various enzymes in plants and other organisms /1-5/. Some work has been published concerning the interaction of vanadium with several amino acids $/ 6-13 /$, and a few with small peptides /14-17/. Most of these studies are devoted to determine the stability constants of the formed complexes and their dependences on ionic strength $/ 18,19 /$, dielectric constant $/ 20 /$, or characterizing their structures by $\mathrm{X}$-ray crystallographic or spectroscopic techniques $/ 21 /$.

A study of available investigations on complex formation reaction between dioxovanadium(V) ion with di- or tripeptides has so far revealed a surprising lack of information concerning these systems, and furthermore suggested that the few available results for complexation of $V(I V)$ and V(V) ions with some peptides disagree about the nature of the species formed. 
Jaswal and Tracey /15/ determined the formation constants of vanadate complexes with some peptides and characterized their structures using ${ }^{51} \mathrm{~V}$ NMR, and suggested monovanadate-monoligand complexes require the terminal amino, the carboxylate groups, and unsubstituted nitrogen in the peptide linkage in order for product formation to occur. They showed that, for complexes to be formed from $\mathrm{VO}_{4} \mathrm{H}_{2}{ }^{-}$and a neutral peptide, giving off protons was not required, but when the carboxylate was replaced by the alcohol functionality a proton was released. Crans and Shin $/ 22 /$ characterized the preferred coordination geometry of vanadium $(V)$ in aqueous solution with nitrogen and oxygen contained in some multidentate ligands including glycylglycine, using ${ }^{1} \mathrm{H},{ }^{13} \mathrm{C},{ }^{51} \mathrm{~V}$, and ${ }^{17} \mathrm{O}$ NMR spectroscopy, $1 \mathrm{R}$, and UVvis spectrophotometric techniques. On the basis of their studies, at high $\mathrm{pH}$, four functionalities chelate vanadium when at least one of them is a carboxylate, and at low $\mathrm{pH}$ only three functionalities in these ligands are tightly bound to the vanadium, while the last functionality is either loosely bound or pendent. Costa Pessoa et al. /14/ studied the system $\mathrm{VO}^{+2}$ with several dipeptides in the $\mathrm{pH}$ range $(1.5-13)$ by a combination of spectroscopic methods (EPR, circular dichroism, and visible absorption). They characterized the structures of the complexes and concluded that there is no evidence for $\mathrm{N}_{\text {amidi }}$ to take part in complexation, but $\mathrm{O}_{\text {amids }}$ is required for the formation of MHL stoichiometry. Tasiopoulos et al. /17/ studied the oxovanadium (IV) and (V) oxidation states with some sulphydryl-containing pseudopeptides and peptides using NMR and EPR techniques. They showed glycylglycine is ligated to vanadium at $\mathrm{N}_{\text {amide }}, \mathrm{N}_{\text {aminct }}$, and $\mathrm{O}_{\text {carbnxylatc }}$ donor atoms. This result was supported by $\mathrm{X}$-ray crystallography.

The present work deals with the study of dioxovanadium(V), $\mathrm{VO}_{2}{ }^{+}$, complexes by some dipeptides included: glycylglycine (glygly), glycyl-Lalanine, glyala, and glycyl-L-phenylalanine (glypheala). The sludy of $\mathrm{VO}_{2}{ }^{+}+$ glycinc interaction was also attempted in order to understand better the influence of the presence of an amide group in the stability of the ligands binding to the metal ion.

\section{EXPERIMENTAL SECTION}

\section{Reagents.}

Glycine, glygly, glyala, and glypheala were supplied from Fluka and were used without further purification. The $\mathrm{NaOH}$ solution was prepared from 
titrisol solution (E. Merck) and its concentration was determined by several titrations with standard $\mathrm{HCl}$. Perchloric acid, sodium perchlorate and sodium monovanadate were supplied from E. Merck as analytical reagent grade materials and were used without further purification. Dilute perchloric acid solution was standardized against standard $\mathrm{NaOH}$ solution. Vanadium(V) solution was standardized titrimetrically against a standard iron(II) sulfate solution /23/. All dilute solutions were prepared from double-distilled water with specific conductance equal to $(1.3 \pm 0.1) \mu \Omega^{-1} \mathrm{~cm}^{-1}$.

\section{Measurements}

All measurements were carried out at $(25 \pm 0.1)^{\circ} \mathrm{C}$. The ionic strength

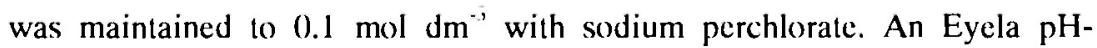
meter, PHM 2000, was used for $\mathrm{pH}$ measurements. The hydrogen ion concentration was measured with an Ingold UO 3234 glass electrode and an Ingold UO 3236 calomel electrode. The $\mathrm{pH}$-meter was calibrated for the relevant $\mathrm{H}^{+}$concentration with a solution of $1.00 \times 10^{2} \mathrm{~mol} \mathrm{dm}{ }^{-i}$ perchloric acid solution containing $0.09 \mathrm{~mol} \mathrm{dm}^{-1}$ sodium perchlorate (for adjusting the ionic strength on $0.1 \mathrm{~mol} \mathrm{dm}^{-3}$ ). For this standard solution, we set $-\log \left[\mathrm{H}^{\prime}\right]=$ 2.00 $/ 9 \%$. Spectrophotometric measurements were performed on a UV-vis Shimadzu 2100 spectrophotometer with GDU-20 computer and using thermostated matched $10 \mathrm{~mm}$ quartz cells. The measurement cell was a $110 \mathrm{w}$ type. A Masterllex pump allowed circulation of the solution under study from the potentiometric cell to the spectrophotometric eell, so the absorbance and $\mathrm{pH}$ of the solution could be measured simultaneously.

For each experiment an acidic solution of $\mathrm{VO}_{2}^{+}\left(10^{-4} \mathrm{~mol} \mathrm{dm}^{-5}\right)$ was titrated with an alkali solution of the ligands (containing a large exeess of each ligand, $\left.0.01 \mathrm{~mol} \mathrm{dm}^{-3}\right)$, both in the same ionic media. The $-\log \left[\mathrm{H}^{-}\right]$and the absorbance were measured after addition of a few drops of titrant, and this procedure extended up to the required $-\log \left[\mathrm{H}^{\prime}\right]$. In all cases, the procedure was repeated at least three times and the resulting average values and corresponding standard deviations are shown in the text and Tables.

\section{RESULTS AND DISCUSSION}

The complex $\mathrm{M}_{\mathbf{r}} \mathrm{H}_{\mathrm{y}} \mathrm{L}_{z}{ }^{(1 \mathrm{x}+\mathrm{y}-1)+}$ formed is characterized by its stoichiometry (x:y: 2 ), where $M$ and $L$ represent the metal ion and the ligand, respectively. To determine the stability constants of complexation or protonation, Eq 1 is 
defined by $\beta_{\mathrm{xyz}} / 9 /$,

$$
\begin{aligned}
& \mathrm{xM}^{+n}+\mathrm{yH}^{+}+\mathrm{zL}^{-} \leftrightarrows \mathrm{M}_{\mathrm{x}} \mathrm{H}_{\mathrm{y}} \mathrm{L}_{z}^{(n x+y-z)+} \\
& \beta_{x y y}=\left[M_{x} H_{y} L_{z}^{(n x+y-z)+}\right] /\left(\left[M^{+n}\right]^{x}\left[H^{+}\right]^{y}\left[L^{-}\right]^{z}\right.
\end{aligned}
$$

The protonation constants of the ligands have been used for computation of the stability constant, $\beta_{\mathrm{xyz}}$, of the metal-ligand. The protonation constants of the ligands have been extensively studied in different kind of background electrolytes, and the results were reported in the literature. The protonation constants have been determined using potentiometric techniques and calculated using a computer program which employs a least-squares method 124,25/. These values are listed in Table I together with the values reported in literature, which are in good agreement with those reported before.

\section{Table I}

Protonation constants of the carboxylic, $\beta_{011}$, and the amino, $\beta_{021}$, groups of

\begin{tabular}{|c|c|c|c|c|}
\hline species & $\log \beta_{011}$ & $\log \beta_{021}$ & $\begin{array}{c}\text { experimental } \\
\text { conditions }\end{array}$ & ref. \\
\hline glycine & $2.43 \pm 0.01$ & $9.80 \pm 0.15$ & & this work \\
\hline glycylglycine & $3.10 \pm 0.12$ & $8.16 \pm 0.15$ & & this work \\
\hline glycylalanine & $3.20 \pm 0.11$ & $8.22 \pm 0.14$ & & this work \\
\hline $\begin{array}{l}\text { glycylphenyl- } \\
\text { alanine }\end{array}$ & $3.11 \pm 0.14$ & $8.14 \pm 0.17$ & & this work \\
\hline glycine & & 9.82 & $\begin{array}{c}\mathrm{I}=0.1 \mathrm{M}, \mathrm{NaClO}_{4}, \mathrm{t} \\
=25^{\circ} \mathrm{C}\end{array}$ & 32 \\
\hline glycine & 2.44 & 9.68 & $\begin{array}{c}\mathrm{I}=0.1 \mathrm{M}, \mathrm{NaNO}_{3}, \mathrm{t} \\
=25^{\circ} \mathrm{C}\end{array}$ & 33 \\
\hline glycylglycine & 3.11 & 8.15 & $\begin{array}{c}\mathrm{I}=0.1 \mathrm{M}, \mathrm{NaClO}_{4}, \mathrm{t} \\
=25^{\circ} \mathrm{C}\end{array}$ & 34 \\
\hline glycylglycine & 3.04 & 7.99 & $\begin{array}{c}\mathrm{I}=0.2 \mathrm{M}, \mathrm{NaClO}_{4}, \mathrm{t} \\
=25^{\circ} \mathrm{C}\end{array}$ & 35 \\
\hline glycylalanine & 3.03 & 8.07 & $\begin{array}{c}\mathrm{I}=0.2 \mathrm{M}, \mathrm{NaClO}_{4}, \mathrm{t} \\
=25^{\circ} \mathrm{C}\end{array}$ & 35 \\
\hline glycylalanine & 3.17 & 8.25 & $\begin{array}{c}\mathrm{I}=0.1 \mathrm{M}, \mathrm{NaClO}_{4}, \mathrm{I} \\
=25^{\circ} \mathrm{C}\end{array}$ & 34 \\
\hline $\begin{array}{l}\text { glycylphenyl- } \\
\text { alanine }\end{array}$ & 3.12 & 8.16 & $\begin{array}{c}1=0.1 \mathrm{M}, \mathrm{NaClO}_{4}, \mathrm{l} \\
=25^{\circ} \mathrm{C}\end{array}$ & 36 \\
\hline
\end{tabular}
the ligands at $25^{\circ} \mathrm{C}$ and ionic strength, $\mathrm{I}, 0.1 \mathrm{~mol} \mathrm{dm}^{-3} \mathrm{NaClO}_{4}$ 
The ligand protonation constants for the peptides follow the expected patterns. Substitution at the $\alpha$-carbon of the carboxy amino acid residue is too far from the free amino group to appreciably affect its protonation constant, so that for the series of glycyl-peptides, $\log \beta_{021} \equiv 8.2$ and $\log \beta_{011} \equiv 3.2$. Although there is an inductive tendency in the phenyl group of glypheala to increase the basicity of the amino and decrease the acidity of carboxyl groups, the possibility of a steric effect in the molecule and the nature of this weak donating decrease this tendency. However, a comparison between the protonation constants of glycine and glycylpeptides shows that the presence of a nucleophilic amide group close to the $\alpha$-carbon in glycylpeptides decreases the basicity of the amino and increases the acidity of the carboxyl groups, causing a smaller protonation constant for the amino and a greater one for the carboxyl groups of glycylpeptides in comparison with glycine.

The method of determination of the stability constant based on the relationship $A=f^{\prime}(p H)$ was employed $/ 26 /$. Absorbance, $A$, and $-\log \left[\mathrm{H}^{+}\right]$were measured for a solution containing dioxovanadium(V) with a large excess of each ligand at different $-\log \left[\mathrm{H}^{+}\right]$, and the results are listed in Table II. To avoid isopolyvanadate formation, the $\mathrm{pH}$ of the solutions was lowered by adding appropriate $\mathrm{HClO}_{4}$ solution; they were allowed to stand overnight before use. Under these conditions both polymerization and hydrolysis of $\mathrm{VO}_{2}{ }^{+}$were negligible $/ 26,27 /$.

\section{$\mathrm{VO}_{2}{ }^{+}+$peptides Systems}

Considering the protonation constants of the peptides, in acidic $\mathrm{pH}$ the predominant species for complexation is HL. In this case the spectrophotometric titration data were analysed by using the absorbance of $\mathrm{VO}_{2}{ }^{+}+$each peptide at wavelengths in the UV range that is given by

$A=\varepsilon_{M}\left[\mathrm{VO}_{2}{ }^{+}\right]+\varepsilon_{\mathrm{C}}[$ complex $]$

where $\varepsilon_{M}$ and $\varepsilon_{c}$ are the molar absorptivities of $\mathrm{VO}_{2}{ }^{+}$and the formed complex by each peptides, respectively. For the mass balance

$$
\begin{aligned}
& {\left[\mathrm{VO}_{2}{ }^{\prime}\right]=\mathrm{C}_{\mathrm{M}}-[\text { complex }]} \\
& {[\mathrm{HL}]=\mathrm{C}_{\mathrm{L}}-\mathrm{h}[\text { complex }]}
\end{aligned}
$$




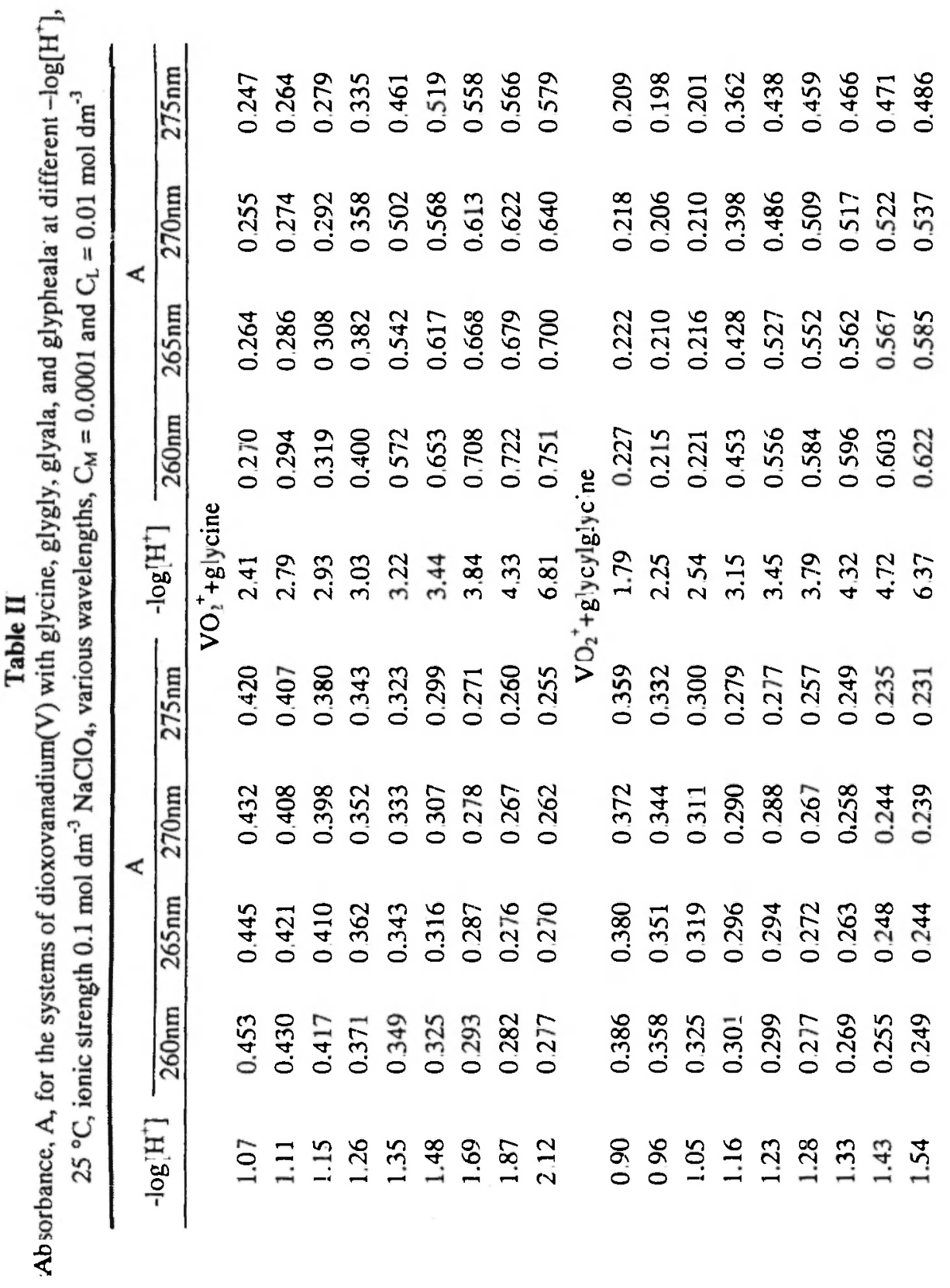




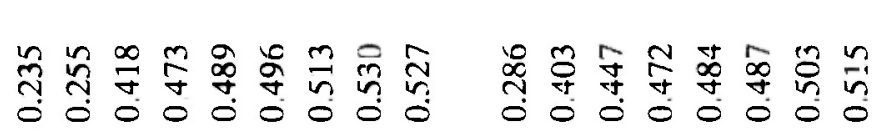

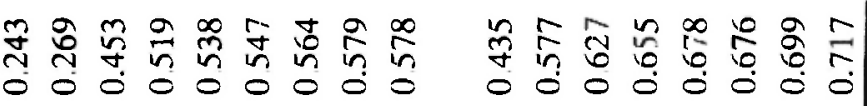

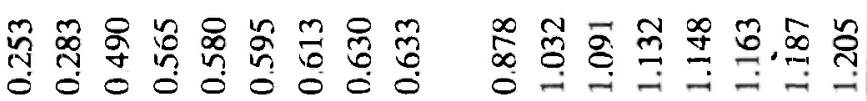

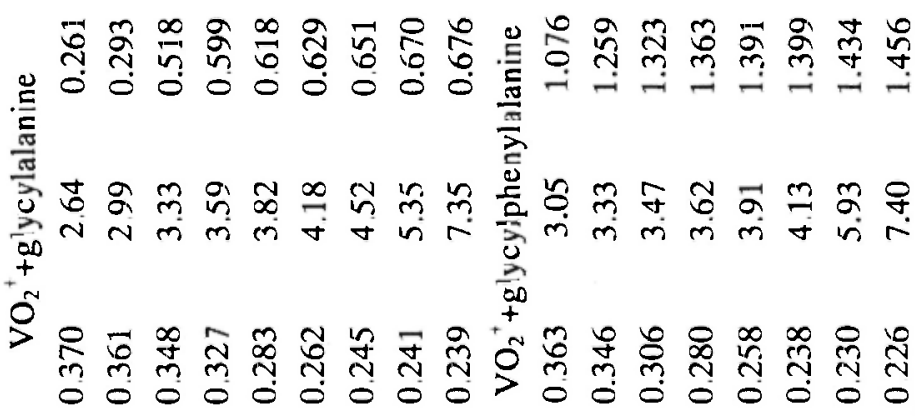

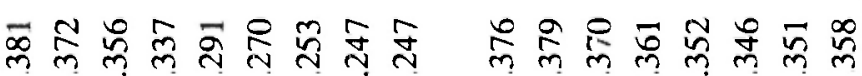
ڤ̆

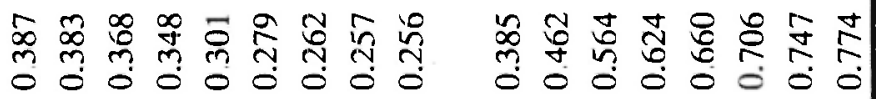
๙

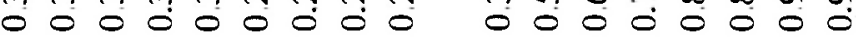

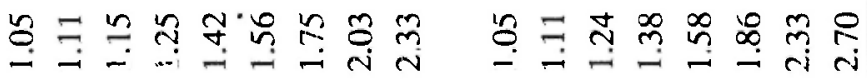


where $C_{M}$ and $C_{L}$ are the total concentration of $\mathrm{VO}^{+}$and each peptide, respectively, and $h$ denotes the number of each peptide molecule bound to a metal ion. Substituting Eqs 2 and 4-5 into Eq 3 and rearranging and canceling like terms gives

$$
\begin{aligned}
A= & \varepsilon_{M} C_{M}+(0.5 / h)\left(\varepsilon_{C^{-}} \varepsilon_{M}\right)\left(h C_{M}+C_{L}+\left[H^{+}\right] / \beta_{x y y .}\right) \pm \\
& (0.5 / h)\left(\varepsilon_{C}-\varepsilon_{M}\right)\left\{\left(h C_{M}+C_{L}+\left[H^{+}\right] / \beta_{x y s}\right)^{2}-4 h C_{M} C_{L}\right\}^{0.5}
\end{aligned}
$$

The method of determining $\varepsilon_{\mathrm{M}}$ was previously described $/ 28 /$ and its values at different wavelengths are used in this work. Using a suitable computer program /29/ the data were fitted to Eq 6 for estimating the formation constant of $\mathrm{Eq}$. We used the Gauss - Newton nonlinear least squares method in computer program to refine the absorbance by minimizing the error squares sum from Eq 7

$$
U=\sum\left(a_{1}-b_{i}\right)^{2} \quad(i=1,2,3, \ldots)
$$

where $a_{1}$ is a quasi-experimental and $b_{1}$ is a calculated one.

In the fitting program, where $h$ is selected to one, $U$ approaches to a minimum value, confirming the formation of a single complex with the formula $\mathrm{VO}_{2} \mathrm{HL}^{\prime}$. If we define $\varepsilon / 30$ / as

$$
\varepsilon=\varepsilon_{M} X_{M}+\varepsilon_{c} \cdot X_{C}
$$

then through the rearrangement of Eq 8 , the average ligand number, $\bar{n}$, can be calculated directly from Eq. 9

$$
\bar{n}=\left(\varepsilon-\varepsilon_{M}\right) /\left(\varepsilon_{C}-\varepsilon_{M}\right)
$$

where $X_{M}$ and $X_{1}$ are the mole fractions of $\mathrm{VO}_{2}$ and $\mathrm{VO}_{2} \mathrm{HL}$, respectively. Calculation has shown $\bar{n}$ equals $0.98(\mathrm{pH} 1.51), 0.98(\mathrm{pH} 1.43)$, and $0.97(\mathrm{pH}$ 1.45 ) for the studied complexes of $\mathrm{VO}_{2}$ by glygly, glyala, and glypheala, respectively. The average values of the stability constants at different wavelengths for the formed mononuclear $1: 1$ complexes, $\beta_{111}$, with $\mathrm{VO}_{2}{ }^{+}$are listed in Table III.

For finding the other proposed species, at higher $\mathrm{pH}$, the spectrophotometric titration data were analysed by offering the following species to the computer program: $\mathrm{VO}_{2} \mathrm{~L}, \mathrm{VO}_{2} \mathrm{HL}_{2}, \mathrm{VO}_{2} \mathrm{H}_{3} \mathrm{~L}_{2}{ }^{+2}$. As expected, 
all the proposed species were systematically rejected by the computer program except $\mathrm{VO}_{2}(\mathrm{HL})_{2}{ }^{+}$. A value for $\mathrm{VO}_{2} \mathrm{~L}$ formation constant was calculated by the program, but the species was not further considered because the estimated error in its formation constant is unacceptable, and its inclusion does not improve the quality of the fit. The model finally chosen, formed by $\mathrm{VO}_{2} \mathrm{HL}^{+}$and $\mathrm{VO}_{2}(\mathrm{HL})_{2}{ }^{+}$, resulted in a satisfactory numerical and graphical fitting. The second complex must be attributed to

$$
\mathrm{VO}, \mathrm{HL}^{+}+\mathrm{HL} \leftrightarrows \mathrm{VO}_{2}(\mathrm{HL})_{2}^{+}
$$

and its stability constant, $\beta_{122}$, was determined in the usual manner, using Eq. 11

$$
\begin{aligned}
A= & \varepsilon_{c} C_{M}+0.5\left(\varepsilon_{C *-} \varepsilon_{C}\right)\left(C_{L}+\left[H^{+}\right] / \beta_{122}\right) \pm \\
& 0.5\left(\varepsilon_{C} *-\varepsilon_{C}\right)\left\{\left(C_{L}+\left[H^{+}\right] / \beta_{122}\right)^{2}-4 C_{M} C_{L}+4 C_{M}\right\}^{20.5}
\end{aligned}
$$

where $\varepsilon_{\mathrm{C}^{*}}$ is the molar absorptivity of $\mathrm{VO}_{2}(\mathrm{HL})_{2}{ }^{+}$. The average values of $\beta_{122}$ at various wavelengths are listed in Table III.

\section{Table III}

Average values of $\log \beta_{111}$ and $\log \beta_{122}$ for the systems of $\mathrm{VO}_{2}{ }^{+}+$glycylpeptides and glycine complexes at different wavelengths

\begin{tabular}{|c|c|c|c|c|}
\hline species & $\log \beta_{111}$ & $\log \beta_{122}$ & & ref. \\
\hline glycine & $3.48 \pm 0.05$ & $7.26 \pm 0.09$ & & this work \\
\hline glycylglycine & $4.31 \pm 0.05$ & $8.83 \pm 0.10$ & & this work \\
\hline glycylalanine & $4.32 \pm 0.04$ & $8.63 \pm 0.09$ & & this work \\
\hline glycylphenylalanine & $4.04 \pm 0.03$ & $5.99 \pm 0.06$ & & this work \\
\hline alanine & 3.28 & 7.26 & & 37 \\
\hline alanylglycine & 4.61 & 8.55 & & 37 \\
\hline alanylalanine & 4.66 & 8.74 & & 37 \\
\hline
\end{tabular}

\section{$\mathrm{VO}_{2}{ }^{+}$- glycine System}

In aqueous solution, glycine exists in its anionic form ( $\left.\mathrm{L}^{*}\right)$, zwitterionic species (HL), and cationic form $\left(\mathrm{H}_{2} \mathrm{~L}^{\prime}\right)$. In acidic $\mathrm{pH}$, in this case, the predominant species for complexation is $\mathrm{HL}$. The spectrophotometric titration data were analysed as before. The model finally chosen, formed by 
$\mathrm{VO}_{2} \mathrm{HL}^{+}$and $\mathrm{VO}_{2}(\mathrm{HL})_{2}{ }^{+}$, resulted in a satisfactory numerical and graphical fitting. The data were fitted to eq 6 and 11 for calculating the formation constants of $\mathrm{Eq} 1$ and the average values of $\beta_{111}$ and $\beta_{122}$ for various wavelengths are collected in Table III.

Since two positions of the oxometal ion are blocked by oxygen atoms, and in view of the preference of $\mathrm{VO}_{2}{ }^{+}$for octahedral configuration in its complexes $/ 31 /$, it is likely that $\mathrm{VO}_{2}$ takes part in complex formation by two molecules of a potentially bidentate ligand. Similar results were obtained by Lagrange et al. in UV and IR spectrophotometric methods /9/.

As can be seen from Table III, the values of $\log \beta_{111}$ and $\log \beta_{122}$ for the series of $\mathrm{VO}_{2}{ }^{+}+$glycylpeptides complexes are nearly identical due to the similarity in their structures, with some influence from the side groups. However, the inductive effect of the side groups in glygly (proton), glyala (methyl group), and glypheala (phenyl- $\mathrm{CH}_{2}$ group) are in increasing affinity order, and so are apparently responsible for the small differences in the calculated values for the stability constants. This assumption has been confirmed by the finding that the stability constant value of the complex with MHL and $\mathrm{M}(\mathrm{HL})_{2}$ stoichiometries formed by glypheala has the lowest value. This could probably be ascribed to the inductive effect of the ligand. A difference between the stability constant values of the glycylpeptides complexes and glycine with $\mathrm{VO}_{2}{ }^{+}$, about $1.6 \mathrm{log}$ units, is probably due to the nucleophilic influence of an amide group close to $\alpha$-carbon in the dipeptide molecules. Although glycine has a smaller size than the dipeptide molecules, the nature of binding caused by an electron attractive tendency of the amide group in glygly, glyala and glypheala is apparently responsible for the differences. In similar studies for $\mathrm{VO}_{2}{ }^{+}$alanylglycine, alanylalanine, and alanine $/ 37 /$, almost the same result as well as the same stoichiometries for the complex species were obtained (Table 3 ), in the order of higher stability constant values as:

glygly $>$ alanylalanine $>$ glyala $>$ alanylglycine $>$ glypheala

In Figure 1 the equilibrium distribution of various species in $\mathrm{VO}_{2}+$ glyala system is shown as a function of $-\log \left[\mathrm{H}^{\prime}\right]$. The calculations are based on the stability constants given before. This Figure shows that when the $\log \left[\mathrm{H}^{\dagger}\right]$ approaches to 1.43 and 2.41 the mole fractions of the proposed complexes have the maximum values, very close to one. 


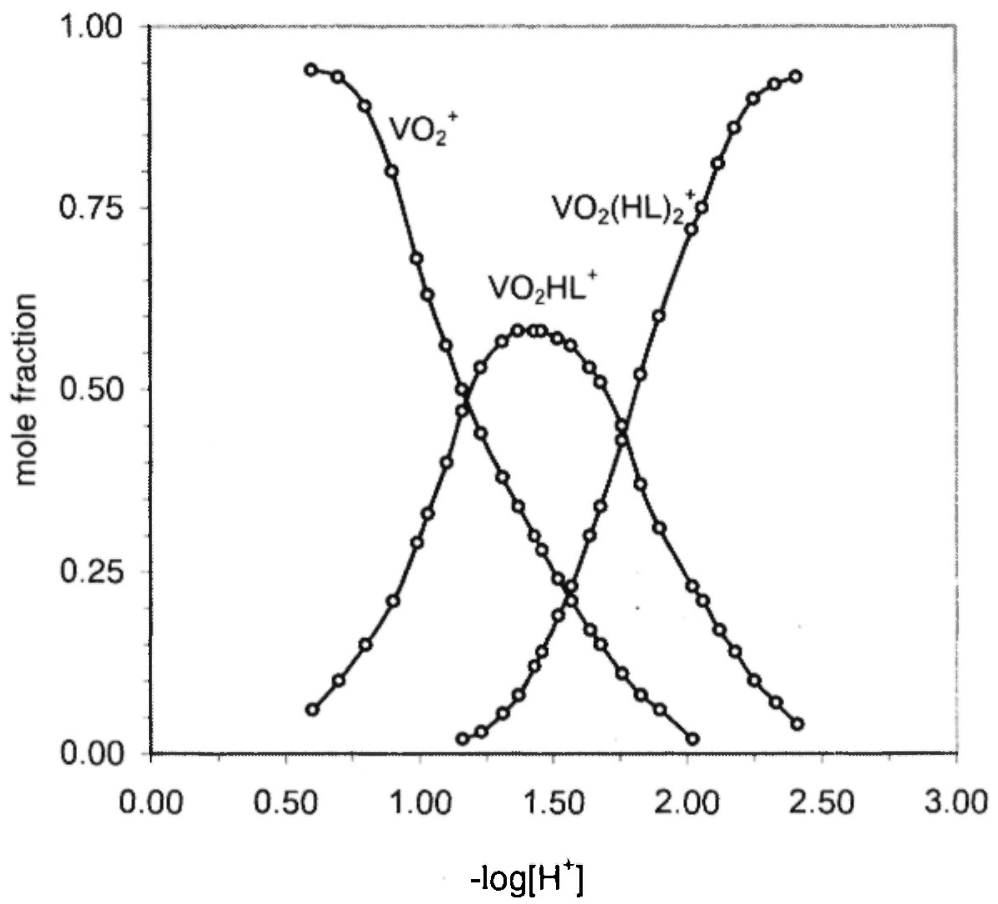

Fig. 1: The equilibrium distribution of the species in glyala $+\mathrm{VO}_{2}{ }^{+}$system as a function of $-\log \left[\mathrm{H}^{+}\right]$at $\mathrm{I}=0.1 \mathrm{~mol} \mathrm{dm}^{-3} \mathrm{NaClO}_{4}$ and $25^{\circ} \mathrm{C}$.

\section{ACKNOWLEDGEMENTS}

Thanks are gratefully extended to the Research Council of Shahid Beheshti University for its financial support of this work.

\section{REFERENCES:}

1. A.C. Tracey and D.C. Crans, Vanadium Compounds, American Chemical Society Series, Washingdon DC, 1998.

2. N.D. Chasteen, J.K. Grady and C.E. Holloway, Inorg. Chem., 25, 2754 (1987).

3. S.M. Ashraf and W.U. Malik, J. Inorg. Biochem., 35, 1 (1989). 
4. W.R. Harris, Biochemistry, 24, 7412 (1985).

5. A. Butler and C.J. Carrano, Coord. Chem. Rev., 109, 61 (1991).

6. J. Costa Pessoa, L.F. Vilas Boas, R.D. Gillard and R.J. Lancashire, Polyhedron, 7, 1245 (1988).

7. J. Costa Pessoa, R.L. Marques, L.F. Vilas Boas and R.D. Gillard, Polyhedron, 9, 81 (1990).

8. J. Costa Pessoa, L.F. Vilas Boas, R.D. Gillard, Polyhedron, 8, 1173 (1989).

9. P. Lagrange, M. Schneider, K. Zare and J. Lagrange, Polyhedron, 13, 861 (1994).

10. F. Gharib, K. Zare and S.A. Khorrami, J. Chem. Eng. Data, 38, 602 (1993).

11. F. Gharib, K. Zare and S.A. Khorrami, J. Chem. Eng. Data, 40, 186 (1995).

12. F. Gharib, A.S. Sadjadi and F. Zourofi, Rev. Inorg. Chem., 20, 219 (2000).

13. F. Gharib, M. Monajjemi, S. Ketabi and F. Zourofi, Russ. J. Inorg. Chem., 46, 363 (2001).

14. J. Costa Pessoa, S.M. Luz and R.D. Gillard, J. Chem. Soc. Dalton Trans., $1997,569$.

15. J.S. Jaswal and A.S. Tracey, Can. J. Chem., 9, 1600 (1991).

16. D.C. Crans, H. Holst, A.D. Keramidas and D. Rehder, Inorg. Chem., 34, 2524 (1995).

17. A.J. Tasiopoulos, A.N. Troganis, Y. Deligiannakis, A. Evangelou, T.A. Kabanos, J.D. Woolins and A. Slawin, J. Inorg. Biochem., 79, 159 (2000).

18. F. Gharib and N.A. Lahouti Fard, J. Chem. Eng. Data, 45, 210 (2000).

19. F. Gharib, K. Zare and K. Majlesi, J. Chem. Reas., 2000, 186.

20. F. Gharib and M. Mollaie, J. Chem. Eng. Data, 44, 77 (1999).

21. D.C. Crans, M. Mahroof Tahir, O.P. Anderson and M. Miller, Inorg. Chem., 33, 5586 (1994).

22. D.C. Crans and P.K. Shin, J. Am. Chem. Soc., 116, 1305 (1994).

23. G. Charlot, Les Methodes de la Chimie Analytique, Analyse Quantitative Minerale, Masson, Paris, $1961 ; 4^{\text {th }}$ ed.

24. F. Gharib, K. Zare and K. Majlesi, J. Chem. Eng. Data, 45, 833 (2000).

25. D.C. Harris, J. Chem. Ed., 75, 119 (1998).

26. J. Itoh, T. Yotsuyanagi and K. Aomura, Anal. Chim. Acta, 76, 471 (1975). 
27. S. Yamada, J. Nagase, S. Funahashi and M. Tanaka, J. Inorg. Nucl. Chem., 38, 617 .

28. F. Gharib and K. Zare, J. Sci. Isl. Azad Univ., 2, 535 (1992).

29. M. Maeder and A.D. Zuberbuhler, Anal. Chem., 62, 2220 (1990).

30. M.T. Beck and I. Nagypal, Chemistry of Complex Equilibria, Ellis Harwood, New York, 1990.

31. N.N. Greenwood and A. Earnshaw, Chemistry of the Elements, Pergamon Press Lid., Oxford, 1985.

32. M.M. Ahmad and M.M. Shoukry, Chem. Pharm. Bull., 49, 253 (2001).

33. W.E. Van Der Linden and C. Beers, Anal. Chim. Acta, 68, 143 (1973).

34. H. Sigel, Inorg. Chem., 14, 1535 (1975).

35. V. Manjula, D. Chakraborty and P.K. Bhattacharya, Ind. J. Chem., 29, 577 (1990).

36. J.L. Biester and P.M. Ruoff, J. Am. Chem. Soc., 81, 6517 (1959).

37. F. Gharib, M.H. Fekri and A. Shamel, Rev. Inorg. Chem., 23, 111 (2003). 